\title{
Manajemen Risiko pada Badan Amil Zakat Nasional (BAZNAS)
}

\section{Risk Management at Badan Amil Zakat Nasional (BAZNAS)}

\author{
Nina Triyani ${ }^{1}$, Irfan Syauqi Beik ${ }^{2}$, Lukman M Baga ${ }^{3}$ \\ ${ }^{1}$ Pascasarjana Sekolah Bisnis IPB 16151, email: nina3yani@gmail.com \\ ${ }^{2}$ Pusat Studi Bisnis dan Ekonomi Syariah (CIBEST) IPB 16153, email: irfan_beik@ipb.ac.id \\ ${ }^{3}$ Pascasarjana Sekolah Bisnis IPB 16151, email: lukmanmb@yahoo.com
}

\begin{abstract}
Risk occurs at any organization or business activity. It also does not close the possiblility of risk occurs at amil institutions. Types of risk are likely to happen often at amil institutions, namely risk on zakat fund collection, risk on zakat fund management, and risk on zakat fund distribution. Basically, zakat distribution must comply with the 8 ashnaf as written in the QS. At-Taubah: 60. This research was conducted on BAZNAS. The aim of this research is to help amil institutions in managing the possibility of risk, analyze the factors that effect the risks, do the risks mapping on zakat fund collection, zakat fund management, and zakat fund distribution, and also make mitigation to minimize the occurrence of the risks. The datawas collected by using the survey method in internal BAZNAS and using ERM method for analysis.
\end{abstract}

Keywords: BAZNAS, ERM, risk management, zakat, zakat management

\begin{abstract}
Abstrak. Risiko terjadi pada setiap organisasi atau kegiatan bisnis, hal ini pun tidak menutup kemungkinan terjadi risiko pada lembaga amil. Jenis risiko yang kemungkinan sering terjadi pada lembaga amil, yaitu risiko pada pengumpulan dana zakat, risiko pada pengelolaan dana zakat, dan risiko pada pendistribusian dana zakat. Pada dasarnya penyaluran zakat harus sesuai dengan 8 ashnaf seperti yang tertulis dalam QS. At-Taubah: 60. Penelitian ini bertujuan untuk membantu lembaga amil dalam mengelola kemungkinan terjadinya risiko. Penelitian ini dilakukan pada BAZNAS dan bertujuan menganalisis faktor-faktor penyebab terjadinya risiko, melakukan pemetaan risiko pada pengumpulan dana zakat, pengelolaan dana zakat, dan pendistribusian dana zakat, serta melakukan mitigasi untuk meminimalisir terjadinya risiko. Data dikumpulkan dengan menggunakan metode survey terhadap internal BAZNAS dan analisis menggunakan metode ERM.
\end{abstract}

Kata kunci: BAZNAS, ERM, manajemen risiko, manajemen zakat, zakat

\section{PENDAHULUAN}

Zakat adalah rukun Islam yang ketiga. Zakat merupakan ibadah yang menandakan ketaatan seorang hamba kepada Allah SWT, ibadah zakat mengandung dua dimensi, yaitu dimensi vertikal (hablumminAllah) dan dimensi horizontal (hablumminannas). Al-Quran menyebutkan kewajiban berzakat sebanyak 82 kali, ini menandakan bahwa zakat mempunyai peranan penting bagi kehidupan umat manusia.

Zakat sebagai salah satu bentuk konkrit dari jaminan sosial yang disyariatkan oleh ajaran Islam, dalam perkembangan selanjutnya berfungsi sebagai penggerak roda perekonomian umat melalui sektor-sektor produktif yang dikelola oleh penerimanya ${ }^{1}$. Selain itu, zakat dapat menjadi sebuah media untuk mengontrol kesenjangan pendapatan, serta menjembatani celah antara golongan muslim kaya dengan muslim miskin, antara muzaki dengan mustahik, sehingga tidak terjadi monopoli dan penumpukan kekayaan pada sebagian kecil golongan muslim tertentu ${ }^{2}$. Allah

\footnotetext{
${ }^{1}$ Khotimah, K. (2005) Pengaruh zakat produktif terhadap pengingkatan kesejahteraan ekonomi para mustahik. Jurnal EKSIS: Ekonomi Keuangan dan Bisnis. 1(4): 41-68.

${ }^{2}$ Syatir, A, Multifiah, Manzilati, A. (2013) Kelembagaan zakat dan preferensi muzakki. Jurnal Ekonomi Islam Al-Infaq, 4(1): 147-154.
} 
berfirman dalam QS. Al-Hasyr (59): 7, yaitu "supaya harta itu jangan beredar diantara orangorang kaya saja diantara kamu".

Berdasarkan pertemuan perdana International Working Group on Zakat Core Principle (IWGZCP), disepakati bahwa identifikasi risiko dalam pengelolaan zakat merupakan hal yang sangat penting karena akan mempengaruhi kualitas pengelolaan zakat. Ada 4 jenis risiko yang telah terdentifikasi dan dunia perzakatan harus memiliki konsep yang jelas dalam memitigasi risiko-risiko tersebut. Pertama, risiko reputasi dan kehilangan muzaki, kedua risiko penyaluran, ketiga risiko operasional, dan keempat risiko transfer antar negara (Beik, 2014).

Menurut Hafidhuddin dan Beik (2010) dan Andriyanto (2011) bahwa pengelolaan zakat yang profesional, terpercaya dan transparan menjadi sebuah instrumen penting yang dapat memakmurkan dan mengangkat derajat kaum muslim. Selain itu manfaat zakat lebih luas yaitu zakat berguna, bukan hanya bagi Indonesia saja tetapi untuk seluruh penduduk muslim dunia.

Manajemen risiko menjadi suatu keharusan bagi setiap perusahaan (Darmawi, 2008), oleh sebab itu dengan memahami bahwa zakat memiliki maslahah yang sangat besar bagi umat, maka perlu dilakukan penelitian terhadap manajemen risiko pada BAZNAS. Lembaga amil yang dijadikan obyek penelitian adalah BAZNAS hal ini dikarenakan BAZNAS memiliki jangkauan yang sangat luas dalam pengumpulan dan pendistribusian zakat serta mencakup skala nasional.

Lembaga pengelola zakat mempunyai peranan yang sangat strategis untuk melaksanakan ketentuan syariah yang terkait dengan kewajiban menunaikan zakat dan menyalurkan zakat kepada yang berhak menerimanya. Perlu dilakukan penelitian untuk menganalisis manajemen risiko pada pengelolaan zakat pada BAZNAS. Diharapkan penelitian ini bisa menjadi referensi bagi lembaga zakat lainnya. Maka, tujuan dari penelitian ini meliputi: 1) menganalisis faktor-faktor penyebab terjadinya risiko pada BAZNAS, 2) melakukan pemetaan dari kemungkinan (probability) dan dampak (impact) risiko yang terjadi pada risiko pengumpulan dana zakat, pengelolaan dana zakat dan distribusi dana zakat, serta 3) merumuskan upaya-upaya untuk melakukan mitigasi risiko pada BAZNAS.

\section{TINJAUAN PUSTAKA}

\section{Zakat}

Menurut Hafidhuddin (2002) zakat dari segi bahasa mempunyai beberapa arti yaitu keberkahan (al-barakatu), pertumbuhan dan berkembang (al-namaa), kesucian (ath-thaharatu). Zakat secara istilah adalah bagian harta dari harta dengan persyaratan tertentu, yang Allah SWT mewajibkan kepada pemiliknya, untuk diserahkan kepada pemiliknya, untuk diserahkan kepada yang berhak menerimanya, dengan persyaratan tertentu.

Zakat berbeda dengan sumber pendapatan negara lainnya, dimana tanggung jawab membayar zakat merupakan kewajiban bagi umat muslim (Ibrahim, 2008). Allah berfirman dalam QS. AtTaubah: 71 bahwa menunaikan zakat adalah sebagian dari ciri-ciri orang beriman.

"Dan orang-orang yang beriman, lelaki dan perempuan, sebahagian mereka (adalah) menjadi penolong bagi sebahagian yang lain. Mereka menyuruh (mengerjakan) yang ma'ruf, mencegah dari yang munkar, mendirikan shalat, menunaikan zakat dan mereka taat pada Allah dan RasulNya. Mereka itu akan diberi rahmat oleh Allah; sesungguhnya Allah Maha Perkasa lagi Maha Bijaksana". 


\section{Syarat Mengeluarkan Zakat}

Syarat wajib untuk mengelurkan zakat menurut Mufraini (2006) adalah sebagai berikut:

1 Islam. Zakat hanya diwajibkan bagi orang Islam saja. Mengeluarkan zakat merupakan salah satu ketaatan umat Islam dalam menajalani rukun Islam yang ke tiga.

2 Merdeka. Hamba sahaya tidak wajib mengeluarkan zakat sedangkan tuannya wajib mengeluarkannya. Di masa sekarang persoalan hamba sahaya tidak ada lagi. Bagaimanapun syarat merdeka tetap harus dicantumkan sebagai salah satu syarat wajib mengeluarkan zakat karena persoalan hamba sahaya ini merupakan salah satu syarat yang tetap ada.

3 Milik Sepenuhnya. Harta yang akan dizakati hendaknya milik sepenuhnya seorang yang beragama Islam dan harus merdeka. Bagi harta yang bekerjasama antara orang Islam dengan orang lain (non muslim) maka hanya harta orang Islam saja yang dikeluarkan zakatnya. Harta titipan juga tidak diperkenankan dikeluarkan zakatnya, kecuali harta tersebut dikeluarkan langsung oleh pemilik harta yang bersangkutan.

4 Cukup Haul. Cukup sumber zakat tertentu seperti perdagangan, perternakan, emas dan perak, harta tersebut dimiliki genap setahun, selama 354 hari menurut tanggalan hijriah atau 365 hari menurut tanggalan masehi. Sedangkan pada harta pertanian, tidak terkait pada ketentuan haul, harta tersebut dikeluarkan pada saat memetiknya atau memanennya ketika mencapai nisab (Hafidhuddin, 2002).

5 Cukup Nishab. Nishab adalah nilai minimal sesuatu harta yang wajib dikeluarkan zakatnya. Kebanyakan standar zakat harta (mal) menggunakan nilai harga emas saat ini, jumlahnya sebanyak 85 gram. Nilai emas dijadikan ukuran nisab untuk menghitung zakat uang simpanan, emas, saham, perniagaan, pendapatan, dan uang dana pensiun.

\section{Golongan Penerima Zakat}

Orang yang berhak menerima zakat ditetapkan oleh Allah SWT dalam QS. At-Taubah: 60, ada 8 golongan yang menerima zakat.

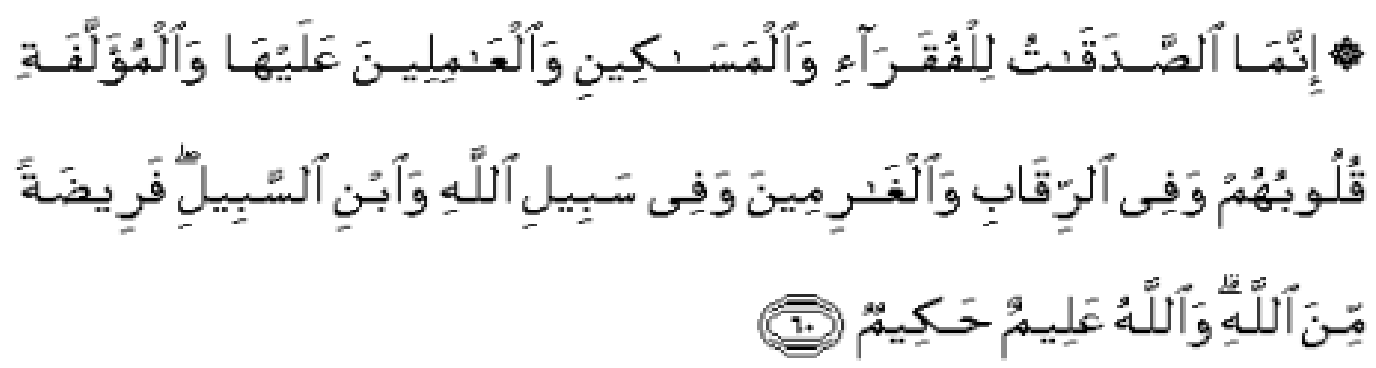

"Sesungguhnya sedekah- sedekah (zakat) itu hanya untuk orang-orang Fakir, Miskin, Pengurus zakat (amil),orang-orang yang telah dibujuk hatinya (muallaf), Untuk memerdekakan budakbudak yang telah dijanjikan akan dimerdekakan, orang yang berhutang (gharim), untuk dijalan Allah (sabilillah) dan untuk orang musafir (orang yang dalam perjalanan). Yang demikian ketentuan Allah"

Dari ayat Al-Quran di atas dengan jelas disebutkan bahwa fakir dan miskin mendapat urutan pertama dan kedua, karena mereka adalah dua golongan utama yang harus didahulukan kepentingannya. Menurut Apriansyah (2011) bahwa program penyaluran dana zakat lebih difokuskan pada fakir miskin. Mereka adalah golongan orang-orang yang tidak dapat mencukupi biaya dan kebutuhan hidup sehari-hari. Kebutuhan tersebut berupa makanan, pakaian, tempat tinggal, pengobatan, pendidikan, dan lainnya, baik bagi dirinya sendiri maupun bagi orang yang menjadi tanggungannya, seperti anak dan istri.

Golongan ketiga yang disebutkan Allah SWT adalah amil. Golongan ini yang berhak menerima dana zakat. Zakat diberikan kepada amil, baik petugas amil yang kaya maupun miskin. Zakat 
diberikan kepada mereka bukan karena kemiskinan tapi sebagai upah atas kerja dalam mengelola dana zakat. Sistem zakat yang dijalankan secara profesional oleh amil maka dapat meningkatkan tingkat kesejahteraan para mustahik. Dalam konsep fiqih amil mendapatkan hak zakat maksimal sebesar 1/8 persen atau 12.5\% persen dari jumlah dana zakat yang terkumpul (Mufraini, 2006). Pada zakat fitrah di bulan Ramadhon para petugas amil tidak berhak mendapatkan 1/8 atau 12.5\% dari zakat yang dikumpulkan, mereka hanya berhak mendapatkan seperlunya saja untuk konsumsi ataupun untuk keperluan administratif. Amil berhak mendapatkan 1/8 atau $12.5 \%$ dari harta zakat yang terkumpul ini berlaku pada zakat mal saja (Hafidhuddin, 2002).

Golongan ke empat yaitu muallaf. Pengertian muallaf menjadi lebih luas sesuai dengan perkembangan, muallaf diklasifikasikan menjadi empat macam yaitu: pertama, orang yang sudah masuk Islam tetapi niat dan imannya masih lemah. Kedua, orang yang telah masuk Islam, niat dan imannya sudah cukup kuat, dan juga terkemuka (tokoh) dikalangan kaumnya. Ketiga, muallaf yang mempunyai kemampuan untuk mengantisipasi tindak kejahatan yang datang dari kaum kafir. Keempat, muallaf yang mempunyai kemampuan mengantisipasi kejahatan yang datang dari kelompok pembangkang wajib zakat (Mufraini, 2006).

Dilihat dari substantif saat ini maka yang termasuk kedalam golongan riqob atau budak adalah para pekerja dengan kempuan dan keterampilan SDM rendah. Pekerjaan yang termasuk kedalam golongan ini yaitu pembantu rumah tangga, mereka sering dianggap "babu" oleh majikan, ini menyerupai atau mendekati perbudakan pada zaman Rasulullah (Mufraini, 2006).

Menurut Qaradhawi dalam Hafidhuddin (2002) yang termasuk kedalam golongan gharimin adalah kelompok orang yang mendapatkan berbagai bencana dan musibah, baik pada dirinya ataupun pada hartanya, sehingga mempunyai kebutuhan mendesak untuk meminjam bagi dirinya dan keluarganya.

Pada zaman Rasullah SAW yang termasuk golongan sabilillah adalah para sukarelawan perang yang tidak mempunyai gaji yang tetap. Pada masa sekarang berdasarkan lafaz dari sabillah di jalan Allah SWT maka penggunaan zakat berkembang, zakat tersebut digunakan untuk membangun masjid, lembaga pendidikan, perpustakaan, pelatihan pada da'i, menerbitkan buku Islami, majalah Islami, brosur, membangun mass media Islami dan lainnya yang mempunyai manfaat besar bagi kebutuhan umat (Hafidhuddin, 2002).

Ibnu Sabil merupakan kiasan untuk musafir (perantau) yaitu orang-orang yang melakukan perjalanan dari satu kota ke kota lain. Ibnu sabil berhak mendapatkan zakat apabila ia kehabisan akomodasi dan perbekalnnya, meskipun ekonominya berkecukupan.

Al-Quran mengilustrasikan ibnu sabil sebagai suatu bentuk aktifitas yang sangat penting, karena Islam senantiasa mendorong untuk melakukan perjalanan dan berpergian dengan beragam motivasi yang ditunjukan Al-Quran di antaranya: berpergian untuk mencari rezeki dan menjemput rezeki, firman Allah dalam QS 67: 15, yaitu "Dialah Yang menjadikan bumi itu mudah bagi kamu, maka berjalanlah di segala penjurunya dan makanlah sebahagian dari rezeki-Nya. Dan hanya kepadaNya-lah kamu (kembali)" dan QS 70: 20 yaitu “Apabila ia ditimpa kesusahan ia berkeluh kesah".

Yang termasuk kedalam ibnu sabil lainya, yaitu perjalanan untuk mencari ilmu, memerhatikan dan merenungkan tanda-tanda kekuasaan Allah di alam semesta, firman Allah dalam QS 29: 20 yaitu" Katakanlah: "Berjalanlah di (muka) bumi, maka perhatikanlah bagaimana Allah menciptakan (manusia) dari permulaannya, kemudian Allah menjadikannya sekali lagi, Sesungguhnya Allah Maha Kuasa atas segala sesuatu” (Mufraini, 2006). 


\section{Manajemen Risiko}

Menurut Hanafi (2006) bahwa risiko muncul karena ada kondisi ketidakpastian. Investasi bisa mendatangkan keuntungan (harga naik), bisa juga menyebabkan kerugian (harga turun). Ketidakpastian tersebut menyebabkan munculnya risiko. Risiko terjadi karena kurang atau tidak tersedianya cukup informasi tentang apa yang akan terjadi. ISO Guide (2009) mendefinisikan risiko yaitu sebagai efek dari ketidakpastian terhadap pencapaian tujuan. Risiko merupakan fungsi kemungkinan sumber ancaman yang dapat menimbulkan potensi kerentanan sehingga akan menghasilkan dampak negatif bagi perusahaan (Lam, 2003).

Setiap peristiwa dapat memiliki dampak negatif, positif atau kedua-duanya. Peristiwa dampak negatif mencerminkan risiko yang dapat mencegah penciptaan nilai atau mengikis nilai yang telah ada. Peristiwa dengan dampak positif merupakan sebuah peluang. Peluang adalah kemungkinan bahwa suatu peristiwa akan terjadi dan secara positif mempengaruhi pencapaian tujuan, mendukung pencapaian nilai atau proses penetapan tujuan perusahaan, merumuskan rencana untuk merebut peluang yang ada (COSO, 2004).

Menurut COSO (2004) Standard of Enterprise Risk Management Integrated Framework (ERM) adalah suatu proses yang dipengaruhi oleh dewan direksi, manajemen dan karyawan lainnya, diterapkan dalam pengaturan strategi melingkupi seluruh perusahaan, yang dirancang untuk mengidentifikasi potensi kejadian yang dapat mempengaruhi entitas, dan pengelolaan risiko yang ada, untuk memberikan kepastian terhadap pencapaian tujuan entitas. Suatu cara (proses atau metode) yang digunakan perusahaan untuk menangani risiko-risiko yang dihadapi dalam usaha mencapai tujuannya (Kountur, 2008).

\section{Model Kerangka Kerja ERM COSO}

Kerangka kerja penelitian ini mengacu pada model kerangka kerja ERM dari COSO. Kerangka kerja ERM COSO merupakan sebuah kerangka kerja dalam Moeller (2007) berbentuk kubus tiga dimensi yang terdiri dari 3 bagian seperti terlihat pada Gambar 1.

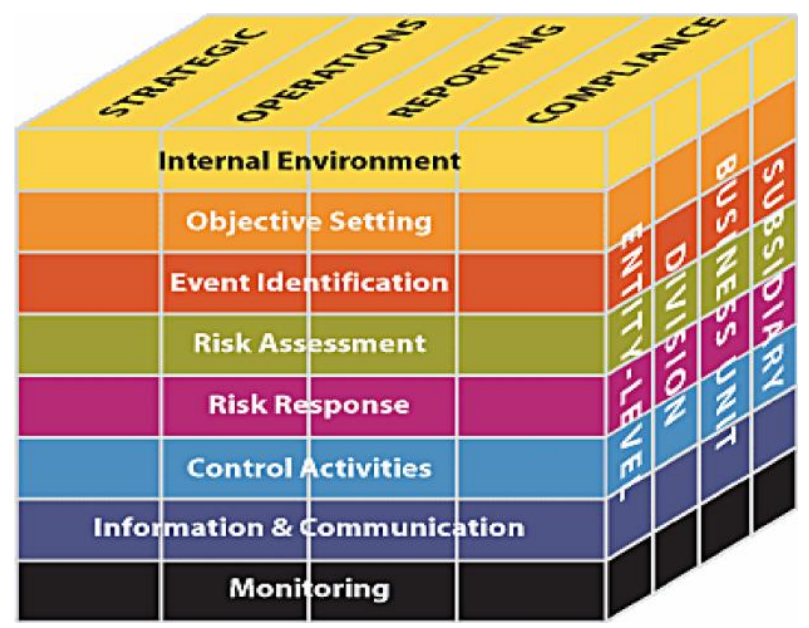

Gambar 1 Kerangka kerja ERM COSO (2004)

Untuk melakukan identifikasi risiko digunakan metode Enterprise Risk Management (ERM). Dengan melakukan pendekatan ERM maka dapat dilakukan identifikasi kemungkinan terjadinya risiko (risk probability), dampak dari risiko (risk impact) dan mitigasi risiko. 


\section{Manfaat Manajemen Risiko}

Menurut Susilo dan Kaho (2011) bila manajemen risiko diterapkan dan dirawat sesuai dengan standar international (ISO 31000), akan memungkinkan tercapainya tujuan organisasi, antara lain untuk dapat:

1 Meningkatkan kemungkinan tercapainya sasaran organisasi

2 Mendorong manajemen yang proaktif

3 Meningkatkan kesadaran untuk mengidentifikasi dan menangani risiko di seluruh bagian organisasi

4 Memperbaiki kemampuan identifikasi ancaman dan peluang

5 Mematuhi peraturan hukum dan perundangan dan standar internasional yang berlaku

6 Memperbaiki sistem pelaporan baik yang wajib maupun yang sukarela

7 Memperbaiki governance organisasi

8 Meningkatkan kemampuan dan kepercayaan pemangku kepentingan

9 Menetapkan suatu landasan yang kokoh dalam pengambilan keputusan dan perencanaan

10 Memperbaiki pengendalian

11 Mengalokasikan dan menggunakan sumber daya secara efektif dan menangani keperluan risiko

12 Meningkatkan kesehatan dan keselamatan kerja dan juga meningkatkan perlindungan terhadap lingkungan hidup

13 Memperbaiki sistem pencegahan kerugian dan pengelolaan tanggap darurat

14 Meminimalkan kerugian

15 Memperbaiki daya tahan organisasi

\section{Kajian Penelitian Terdahulu}

Mufraini (2005) melakukan penelitian yang berjudul Efek Distribusi Produktif Dana Zakat, Infak dan Sedekah (ZIS) pada Perilaku Konsumsi Mustahik. Penelitian menggunakan analisis deskriptif kuantitatif, data responden diperoleh dengan melakukan kuesioner dan wawancara. Dari hasil penelitan menyebutkan bahwa prilaku dan kehidupan mustahik mengalami perubahan yang signifikan setelah mendapatkan dana Zakat, Infak dan Sedekah (ZIS).

Shalihati (2010), Pidianti (2012), Bakar dan Ghani (2011), melakukan penelitian terkait motivasi dan persepsi muzakki dalam membayar zakat pada lembaga amil.

Penelitian ini merupakan penelitian pertama oleh karena itu dalam penelitian ini menggunkanan sumber rujukan yang terkait dengan risiko, manajemen risiko dan Enterprise Risik Manajemen (ERM).

Penelitian analisis risiko dilakukan oleh Irawan (2014), Roeshardianto (2014), dan Wasito (2013), yaitu melakukan penelitian dengan penerapan manajemen risiko pada perusahaan. Dalam penelitian ini dilakukan identifikasi risiko, pemetaan, dan melakukan pengukuran risiko. Kemudian risiko yang telah teridentifikasi dikelompokan ke dalam empat kategori, yaitu finansial, operasional, strategi, dan hazard. Selanjutnya dilakukan strategi dalam mitigasi risiko.

Linawati dan Sanjaya (2015) melakukan penelitian yang berjudul Pengaruh Penerapan Enterprise Risk Management dan Variabel Kontrol terhadap Nilai Perusahaan di Sektor Keuangan. Penelitian ini bertujuan untuk mengetahui pengaruh Enterprise Risk Management (ERM) dengan variabel kontrol yang terdiri dari ukuran perusahaan dan leverage terhadap nilai perusahaan. Metode yang digunakan adalah Regresi Linear Berganda-Ordinary Least Square (OLS), dengan populasi penelitian perusahaan sektor keuangan yang terdaftar di Bursa Efek Indonesia pada periode 20102013. Hasil penelitian menunjukkan bahwa secara bersama-sama ERM dan variabel kontrol yang terdiri dari ukuran perusahaan serta leverage berpengaruh signifikan terhadap nilai perusahaan. 
Namun secara parsial, ERM tidak berpengaruh signifikan terhadap nilai perusahaan. Ukuran perusahaan dan leverage berpengaruh signifikan terhadap nilai perusahaan.

Wiryono dan Suharto (2008) melakukan penelitian yang berjudul Analisis Risiko Operasional di PT Telkom dengan Pendekatan Metode ERM. Penelitian ini menggunakan metode ERM, Operasional Risk dan COSO Framework. Tujuan menggunakan metode ini, yaitu mengidentifikasi dan menilai besarnya dampak dan kemungkinan dari risiko-risiko operasional di TELKOM. Solusi yang menjadi alternatif dalam penelitian ini, yaitu menangani risiko-risiko tersebut dengan cara mengurangi risiko.

\section{METODE}

\section{Jenis, Sumber, dan Metode Pengumpulan Data}

Penelitian ini menggunakan data primer dan data sekunder yang berupa data kualitatif dan kuantitatif. Data primer yang diperoleh dengan penyebaran kuesioner dan wawancara mendalam (in-depth interview) kepada para pakar/ahli Lembaga Amil Zakat (LAZ) ABC. Wawancara dilakukan kepada 6 para pakar zakat, yang mempunyai peranan penting dalam operasional LAZ ABC. Responden dipilih dengan pertimbangan bahwa responden tersebut memiliki pengetahuan, keahlian, dan kompetensi dalam bidang yang dikaji. Penyebaran data kuesioner dan wawancara dilakukan secara langsung di kantor pusat BAZNAS. Data sekunder diperoleh dari jurnal, profil lembaga amil, undang-undang yang terkait penelitian, perpustakaan, website, dan internet.

\section{Teknik Penetapan Responden}

Teknik penetapan responden menggunakan purposive sampling. Dengan metode ini telah dilakukan pemilihan responden dengan pertimbangan bahwa responden yang dipilih memiliki pengetahuan, keahlian, dan kompetensi pada bidang yang diteliti. Responden yang dipilih dalam penelitian ini, yaitu ketua pelaksana BAZNAS, wakil sekretaris BAZNAS, direktur pelaksana BAZNAS, dan kepala divisi pengembangan dan pengendalian, kepala divisi pendistribusian dan pendayagunaan, kepala divisi penghimpunan dan komunikasi lembaga, serta kepala divisi administrasi dan keuangan.

\section{Teknik Pengelolaan dan Analisis Data}

Pengelolahan data risiko dilakukan dengan menggunakan data kuesioner yang telah dilengkapi oleh para pakar BAZNAS, kemudian dilakukan analisis dengan melakukan pengukuran dan pemetaan risiko pada setiap kuesioner. Setelah dilakukan pengukuran dan pemetaan akan diketahui besarnya atau indikator penyebab terjadinya sebuah risiko.

Langkah selanjutnya risiko-risiko tersebut dilakukan pemetaan sesuai dengan perhitungan skor nilai yang diperoleh dari skor nilai pada kemungkinan risiko (risk probability) dan skor nilai pada dampak risiko (risk impact), apakah risiko tersebut termasuk ke dalam golongan negligible (risiko yang tidak perlu dipertimbangkan sehingga bisa diabaikan), acceptable (risiko yang dapat diterima tetapi perlu dikelola), undesirable (risiko yang sebaiknya dihindari), atau unacceptable (risiko yang harus dihilangkan karena berdampak besar bagi BAZNAS). Berikut gambaran secara rinci teknik dalam pengelolaan data yaitu:

\section{Identifikasi Risiko}

Identifikasi risiko merupakan rangkaian dari tahap manajemen risiko. Identifikasi risiko memegang peranan sangat penting yang berpengaruh pada penilaian risiko. Tahapan ini 
merupakan pertama yang dilakukan untuk menentukan risiko-risiko tersebut berpengaruh signifikan atau tidak terhadap pengelolaan zakat pada BAZNAS.

\section{Pengukuran dan Pemetaan Risiko}

Proses pengukuran risiko ini menggunakan metode aproksimasi. Kountur (2008) menjelaskan bahwa metode aproksimasi adalah cara untuk mengetahui probabilitas dan dampak dari suatu risiko kepada orang lain.

Untuk mengukur probabilitas atau kemungkinan terjadinya risiko dapat ditentukan berdasarkan kategori risiko, frekuensi terjadinya risiko dalam kurun waktu tertentu dan pemberian penilaian (scoring). Penggolongan tingkat risiko dilihat berdasarkan frekuensi per tahun, skor 1 melambangkan risiko sangat rendah (improbable) dan skor 5 melambangkan frekuensi sangat tinggi (frequent). Keterangan tingkat kemungkinan atau probabilitas dapat dilihat pada Tabel 1.

Tabel 1 Indikator kemungkinan (probability) terjadinya risiko

\begin{tabular}{lllc}
\hline \multicolumn{1}{c}{ Kategori } & \multicolumn{1}{c}{ Keterangan } & \multicolumn{1}{c}{ Frekuensi } & Skor \\
\hline Improbable (sangat rendah) & $\begin{array}{l}\text { Hampir tidak } \\
\text { mungkin terjadi }\end{array}$ & $\begin{array}{l}<\text { kali per tahun } \\
\text { Remote (rendah) }\end{array}$ & 1 \\
Kadang terjadi & 5-10 kali per tahun & 2 \\
Occasional (sedang) & Mungkin terjadi & $\begin{array}{l}11-20 \text { kali per } \\
\text { tahun }\end{array}$ & 3 \\
Probable (tinggi) & $\begin{array}{l}\text { Sangat mungkin } \\
\text { terjadi }\end{array}$ & $\begin{array}{l}21-50 \text { kali per } \\
\text { tahun }\end{array}$ & 4 \\
Frequent (sangat tinggi) & $\begin{array}{l}\text { Hampir pasti } \\
\text { terjadi }\end{array}$ & $>50$ kali per tahun & 5 \\
\hline
\end{tabular}

Sumber: Godfrey (1996), diolah

Setelah dilakukan pengukuran terhadap kemungkinan atau probabilitas terjadinya risiko, tahap selanjutnya yang dilakukan adalah dengan melakukan pengukuran terhadap dampak terjadinya risiko. Dampak (impact) dapat digolongkan menjadi 5 kategori, mulai dari risiko yang mempunyai dampak yang besar ataupun risiko yang berdampak kecil bagi organisasi. Pada Tabel 2 dapat dilihat dampak terjadinya risiko dengan menggunkan 5 kategori, yaitu negligible, margina, serious, critical, dan catastrophic.

Pada Tabel 3, risiko dengan skor 1-2 termasuk kategori negligible, yaitu risiko yang jarang terjadi dan bila terjadi memiliki dampak yang relatif kecil. Efek dari risiko ini dapat dikurangi, namun biayanya bisa saja melebihi dampak yang dihasilkan. Dalam kasus ini sebaiknya untuk menerima risiko tersebut.

Risiko dengan skor 3-4 termasuk kategori acceptable, yaitu risiko yang memberikan dampak bagi BAZNAS tetapi masih dalam batas toleransi sehingga masih bisa diatasi. Respon paling tepat untuk risiko ini adalah dengan mengurangi risiko. 
Risiko dengan skor 5-12 termasuk kategori undesirable, yaitu risiko yang harus diwaspadai karena sudah melewati batas toleransi dan berpengaruh signifikan terhadap BAZNAS. Respon paling tepat untuk tipe risiko ini adalah dihindari.

Risiko dengan skor diatas 12 termasuk kategori unacceptable, yaitu risiko tinggi karena memberikan pengaruh yang signifikan, merugikan BAZNAS dan memiliki efek domino dalam jangka panjang sehingga harus mendapat prioritas utama. Risiko jenis ini harus dihilangkan atau ditransfer.

Tabel 2 Mengukur dampak (impact) terjadinya risiko

\begin{tabular}{clc}
\hline Kategori & \multicolumn{1}{c}{ Keterangan } & Skor \\
\hline Negligible & Tidak menimbulkan masalah berarti bagi BAZNAS & 1 \\
Marginal & $\begin{array}{l}\text { Menimbulkan masalah kecil yang dapat diatasi dengan } \\
\text { pengelolaan rutin }\end{array}$ & 2 \\
Serious & $\begin{array}{l}\text { Mencegah perusahaan memenuhi tujuannya untuk periode } \\
\text { tertentu }\end{array}$ & 3 \\
Critical & $\begin{array}{l}\text { Mengakibatkan pihak BAZNAS tidak dapat mencapai } \\
\text { sebagian tujuan jangka panjang, menggangu likuiditas. }\end{array}$ & 4 \\
Catastrophic & $\begin{array}{l}\text { Mengakibatkan pihak BAZNAS tidak dapat mencapai } \\
\text { seluruh tujuan jangka panjang, menyebabkan kebangkrutan, } \\
\text { kematian atau hukuman pidana }\end{array}$ & 5 \\
\hline
\end{tabular}

Sumber: Godfrey (1996), diolah

Tabel 3 Tingkat penerimaan risiko

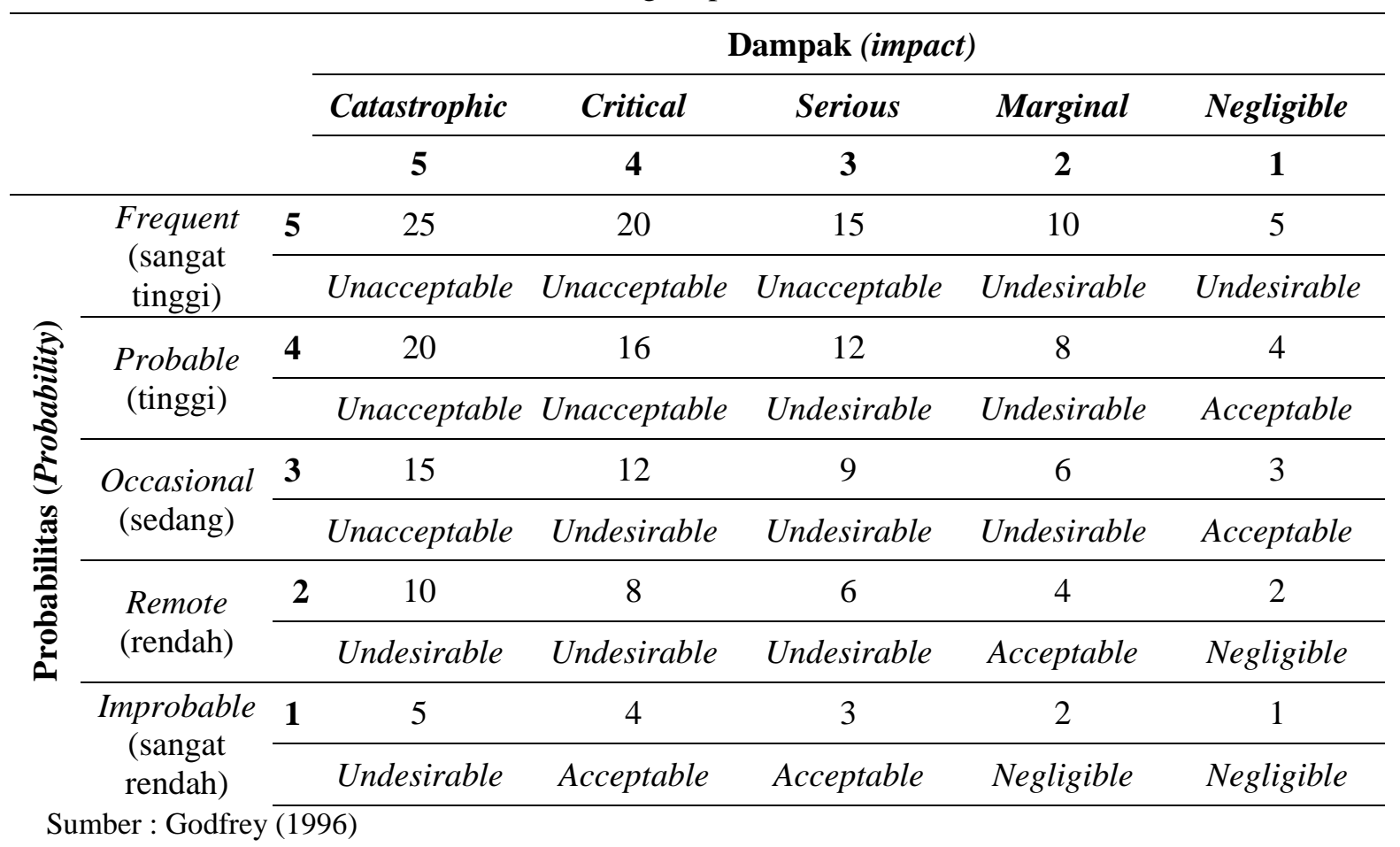




\section{Mitigasi}

Perencanaan strategi mitigasi adalah tindakan yang merupakan proses, teknik, dan strategi untuk mengurangi risiko yang mungkin timbul. Tanggapan yang dilakukan bisa berupa tindakan menghindari risiko dan mentransfer risiko.

\section{HASIL DAN PEMBAHASAN}

\section{Identifikasi Risiko}

ERM 1: Internal Environment

BAZNAS merupakan badan resmi dan satu-satunya yang dibentuk oleh pemerintah berdasarkan Keputusan Presiden RI No. 8 Tahun 2001 yang memiliki tugas dan fungsi menghimpun dan menyalurkan zakat, infaq, dan sedekah (ZIS) pada tingkat nasional.

BAZNAS memiliki misi menjadi badan zakat nasional yang amanah, transparan dan profesional. BAZNAS bersama pemerintah bertanggung jawab untuk mengawal pengelolaan zakat yang berasaskan; syariat Islam, amanah, kemanfaatan, keadilan, kepastian hukum, terintegrasi, dan akuntabilitas.

\section{ERM 2: Objective Setting}

BAZNAS sebagai lembaga sosial yang memiliki sertifikasi ISO 9001:2008. Dalam melaksanakan kegiatannya BAZNAS memiliki visi dan misi. Visi BAZNAS adalah menjadi Badan Zakat Nasional yang amanah, transparan, dan profesional. BAZNAS memiliki beberapa misi, yaitu sebagai berikut:

1 Mengembangkan kompetensi pengelola zakat sehingga menjadi lembaga pilihan utama umat;

2 Membangun pusat rujukan zakat nasional untuk tata kelola, aspek syariah, inovasi program, dan pusat data zakat bagi seluruh pengelola zakat;

3 Mengembangkan kapabilitas pengelolaan zakat berbasis teknologi modern sehingga terwujud pelayanan zakat yang transparan, efektif, dan efisien;

4 Menjalankan pengelolaan yang amanah sehingga mendapat kepercayaan dari masyarakat;

5 Memberikan pelayanan bagi muzaki untuk menunaikan zakat dengan benar sesuai syari'ah;

6 Mengembangkan pelayanan dan program pemberdayaan untuk meningkatkan kesejahteraan mustahik;

7 Mensinergikan seluruh potensi dan kekuatan para pemangku kepentingan (stakeholders) zakat untuk memberdayakan umat.

\section{ERM 3: Event Identification}

Dalam melakukan identifikasi risiko pada BAZNAS dapat dilakukan dengan melalui wawancara langsung kepada pihak-pihak yang terkait dengan jalannya operasional pada BAZNAS. Pada penelitian ini akan dilakukan pembagian risiko yaitu pada faktor internal dan faktor eksternal. Faktor internal meliputi penghimpunan dana, pengelolaan dan pendistribusian sedangkan faktor eksternal mencakup risiko secara umum yang dipengaruhi oleh pihak diluar BAZNAS.

Identifikasi pertama pada penghimpunan dana. Dana yang dizakatkan haruslah memenuhi ketentuan zakat, baik dari nishab ataupun kadarnya. Sumber perolehan dana harus jelas, bukan dari hasil korupsi, bunga bank, judi,dan saham. 
Identifikasi kedua pada pengelolaan dana zakat. Dana zakat yang dikelola dan didistribusikan harus transparasi dan akuntabilitas. Sehingga bisa memberikan kenyamann dan menambah rasa kepercayaan muzaki terhadap BAZNAS.

Identifikasi ketiga pada pendistribusian atau penyaluran. Dalam melakukan penyaluran ini, mustahik yang menerima dana zakat haruslah sesuai dengan 8 ashnaf sesuai dengan QS AtTaubah: 60 "Sesungguhnya sedekah-sedekah (zakat) itu hanya untuk orang-orang Fakir, Miskin, Pengurus zakat (amil),orang-orang yang telah dibujuk hatinya (muallaf), Untuk memerdekakan budak-budak yang telah dijanjikan akan dimerdekakan, orang yang berhutang (gharim) untuk dijalan Allah (sabilillah) dan untuk orang musafir (orang yang dalam perjalanan). Yang demikian ketentuan Allah"

\section{ERM 4: Risk Assessment}

Penilaian risiko pada BAZNAS dilakukan melalui wawancara direktur pelaksana, ketua umum dan wakil seketaris umum, kepala perhimpunan dan komunikasi lembaga, kepala pendistribusian dan pendayagunaan, kepala administrasi dan keuangan.

Hal-hal yang ditanyakan adalah kemungkinan terjadinya risiko yang berkaitan dengan bidang masing-masing dan seberapa besar dampak yang diterima jika risiko tersebut terjadi. Selain wawancara, digunakan juga alat bantu yang berupa kuesioner terbuka mengenai penilaian risiko pengumpulan dana zakat, pengelolaan dana zakat dan pendistribusian dana zakat yang terdapat pada BAZNAS.

Risiko-risiko yang sudah teridentifikasi sebelumnya kemudian dinilai dengan standar pengukuran yang menjadi indikator ukuran risiko. Pada kasus ini, kemungkinan terjadinya risiko dan dampaknya dinilai berdasarkan diskusi dengan direktur pelaksana karena dinilai kompeten dan memahami seluruh kegiatan pengumpulan dana zakat, pengelolaan dana zakat dan pendistribusian dana zakat yang terdapat pada Badan Amil Zakat.

\section{Tindakan Mitigasi Risiko}

\section{ERM 5: Risk Response}

Tindakan mitigasi difokuskan pada risiko yang masuk kedalam kategori high risk ataupun kategori unacceptable, adapun risiko-risiko tersebut adalah sebagai berikut:

1 Risiko pengumpulan dana zakat

1.1 R5; Harta yang dizakatkan tidak sesuai perhitungan zakat (nishab)

Mitigasi:

1.1.1 Merujuk pada UU No. 23 tahun 2011 pasal 21 ayat 1 dan 2, yaitu

a Dalam rangka pengumpulan zakat, muzaki melakukan penghitungan sendiri atas kewajiban zakatnya.

b Dalam hal tidak dapat menghitung sendiri kewajiban zakatnya, muzaki dapat meminta bantuan BAZNAS.

1.1.2 Menyediakan pemisahan rekening, yaitu rekening khusus zakat, infak, dan sedekah.

1.2 R6; Adanya kampanye negatif tentang lembaga amil (muzaki membayar zakat tidak melalui amil)

Mitigasi: BAZNAS memperbaiki kinerja dengan cara

1.2.1 Menunjukan dan memberitahukan kepada masyarakat terhadap kegiatan amil dalam mendistribusikan zakat kepada mustahik.

1.2.2 Memberitahukan kepada masyarakat bahwa BAZNAS menyalurkan zakat kepada mustahik sudah sesuai dengan Al-Quran (8 ashnaf).

1.2.3 Dari sisi manajemen, BAZNAS memberikan pelatihan SDM secara berkala, 
melakukan monitoring terhadap kinerja SDM amil dan memberikan sanksi yang tegas terhadap amil yang melanggar hukum.

1.3 R10; Tidak ada sanksi yang tegas dari pemerintah bagi muzaki yang tidak membayar zakat

Mitigasi: BAZNAS melakukan pendekatan kepada para ulama dengan tujuan melakukan pendekatan kepada pemerintah dalam upaya menerbitkan dan menetapkan peraturan tentang zakat.

$1.4 \mathrm{R} 11$; Adanya persaingan yang tidak sehat dengan lembaga zakat lain

Mitigasi: Merujuk pada UU No. 23 tahun 2011, yaitu

1.4.1. Pasal 18 ayat 1 berbunyi pembentukan LAZ atau BAZ wajib mendapatkan izin dari Menteri atau pejabat yang ditunjuk oleh Menteri.

1.4.2. Pasal 18 ayat 2, yaitu

a Poin (b); berbentuk lembaga berbadan hukum

b Poin (c); mendapatkan rekomendasi dari BAZNAS

c Poin (g); memiliki program untuk mendayagunakan zakat sebagai kesejahteraan umat.

d Poin (h); bersedia diaudit syariah dan audit keuangan secara berkala.

1.4.3. Berdasarkan penjelasan undang-undang diatas, apabila ditemukan lembaga zakat yang tidak patuh dan melanggar aturan maka BAZNAS dapat melakukan pencabutan rekomendasi dalam pembetukan lembaga zakat.

2 Risiko pada pengelolaan dana zakat

2.1 R18; Adanya pemanfaatan dana zakat untuk kepentingan golongan

Mitigasi:

2.1.1 BAZNAS melakukan seleksi yang ketat dalam penerimaan SDM amil, sehingga tercipta petugas amil yang amanah dan jujur dalam melaksanakan tugasnya.

2.1.2 BAZNAS melakukan seleksi yang ketat terhadap setiap mustahik yang akan menerima dana zakat.

2.2 R19; Sebagian dana zakat digunakan untuk biaya operasional amil

Mitigasi:

2.2.1 Zakat yang dapat digunakan oleh amil maksimal $12.5 \%$ atau $1 / 8$ dari dana zakat yang terkumpul.

2.2.2 Apabila persentase dalam pengambilan/penggunaan dana zakat melebihi dari $12.5 \%$ atau 1/8 maka bisa mendapatkan sanksi ataupun hukuman penjara.

2.3 R25; Tidak adanya transparasi dalam pengelolaan dana zakat

Mitigasi:

2.3.1 Mewajibkan BAZNAS untuk menerbitkan laporan keuangan setiap per triwulan, kurtal dan tahuhan.

2.3.2 Memberikan sanksi berupa; (1) peringatan tertulis, (2) penghentian sementara dari kegiatan, (3) pencabutan izin.

2.4 R27; Tidak adanya pelaporan dana zakat secara periodik

Mitigasi:

2.4.1. Merujuk pada UU No. 23 tahun 2011, pasal 7 ayat 3, yaitu BAZNAS wajib melaporkan hasil pelaksanaan tugasnya secara tertulis kepada presiden melalui Menteri dan kepada DPR paling sedikit 1 (satu) kali dalam 1 (satu).

2.4.2. Apabila BAZNAS tidak melaksanakan sesuai pasal 7 ayat 3, maka BAZNAS dapat diberikan sanksi berupa; (1) peringatan tertulis, (2) penghentian sementara dari kegiatan, (3) pencabutan izin. 
2.5 R31; Tidak ada SOP (standard operational procedure) dalam pengelolaan dana zakat Mitigasi: BAZNAS membentuk SOP sebagai standar operasional dalam pengelolaan zakat.

2.6 R39; Lambatnya respon lembaga amil terhadap keluhan masyarakat Mitigasi: BAZNAS menyediakan kotak kritik dan customer service yang berfungsi sebagai penerima setiap keluhan dari masyarakat.

2.7 R40; Lambatnya respon lembaga amil terhadap masukan/saran dari masyarakat Mitigasi: BAZNAS menyediakan kotak saran dan customer service yang berfungsi sebagai penerima setiap masukan ataupun saran dari masyarakat.

2.8 R41; Tidak sinkronnya pelaporan dana zakat antara pusat dan daerah Mitigasi: Membangun sistem dan IT sehingga bisa melakukan controlling terhadap pengelolaan zakat daerah dan pusat.

2.9 R42; Lemahnya manajemen database mustahik

Mitigasi: Membangun sistem pusat database mustahik, sehingga dapat diketahui semua mustahik yang terdaftar pada BAZNAS (pusat dan daerah), hal ini bisa menghindari kesalahan penyaluran zakat ataupun mencegah terjadinya penyaluran zakat 2 kali kepada mustahik.

3 Risiko pada penyaluran/pendistribusian dana zakat

Pada risiko ini tidak terdapat risiko yang termasuk kedalam kategori unacceptale.

\section{ERM 6: Control Activities}

Tindakan pengendalian dilakukan untuk meminimalisasi kerugian yang ditimbulkan oleh risiko dan menjamin respon terhadap risiko berjalan dengan efektif. Pengendalian yang dilakukan dapat berupa deskripsi kerja yang jelas untuk masing-masing karyawan, pengawasan yang ketat terhadap SOP, dokumentasi yang baik di setiap bagian dan adanya pelaksanaan internal audit secara berkala per triwulan, kuartal, dan tahunan.

\section{ERM 7: Information and Communication}

BAZNAS sebagai lembaga amil zakat harus dapat memberikan informasi dan juga dapat mengkomunikasikan segala hal yang terkait dengan zakat dengan baik, jelas dan benar baik kepada muzaki ataupun mustahik. Lembaga amil zakat seperti BAZNAS berasaskan kepercayaan dari masyarakat maka jika terjadi kesalahan, baik dalam memberikan informasi atau dalam segi penyampaian maka hal ini bisa berdampak buruk bagi reputasi BAZNAS itu sendiri.

\section{ERM 8: Monitoring}

Kegiatan monitoring dapat dilakukan melalui proses manajemen yang sedang berjalan dan dilakukan evaluasi secara periodik. Dengan melakukan monitoring dapat diketahui kegiatan operasional yang sedang berjalan, serta dengan melakukan monitoring dapat pula diketahui tingkat kepercayaan dan kepuasan masyarakat terhadap pelayanan BAZNAS. Monitoring pada penelitian ini ditekankan pada risiko yang termasuk kedalam kategori unacceptable, karena risiko ini memilki dampak yang besar bagi operasional BAZNAS. Sebaiknya pada risiko unacceptable dilakukan monitoring secara periodik yaitu; triwulan, kuartal ataupun tahunan. Risiko yang termasuk kedalam kategori unacceptable sebagai berikut:

1 Risiko pada pengumpulan dana zakat

1.1 Harta yang dizakatkan tidak sesuai perhitungan zakat (nishab), pada risiko ini dilakukan monitoring dengan membuatkan sebuah formulir yang berisi sumber pendapatan muzaki selama 1 tahun. 
1.2 Adanya kampanye negatif tentang lembaga amil (muzaki membayar zakat tidak melalui ami), pada risiko monitoring yang dilakukan, yaitu:

a Dengan mencari sumber permasalahan, hal-hal apa yang menyebabkan amil dipandang negatif oleh masyarakat.

b Setelah diketahui sumber permasalahannya dapat dicarikan solusi yang tepat, apabila permasalahannya terdapat pada rendahnya tingkat kepercayaan pada amil, maka langkah yang dapat dilakukan amil yaitu dengan memperbaiki kinerja amil dan memberitakan kepada masyarakat mengenai kegiatan-kegiatan yang telah dilakukan amil dalam penyaluran dana zakat.

1.3 Tidak ada sanksi yang tegas dari pemerintah bagi muzaki yang tidak membayar zakat, pada risiko ini monitoring dilakukan dengan melalui pendekatan dan bekerja sama dengan para ulama, kyai, pemuka agama yang bertujuan memperikan kesadaran kepada para muzaki, bahwa menunaikan zakat adalah sebuah kewajiban bagi umat Islam. Dengan dana zakat yang terkumpul akan mampu membantu kesejahteraan umat, serta dampak dari zakat yang tidak ditunaikan akan membuat para fakir miskin mengalami penderitaan, seperti kekurangan pangan, terlantar, putus sekolah, dan tidak mempunyai tempat tinggal.

1.4 Adanya persaingan yang tidak sehat dengan lembaga zakat lain, pada risiko ini dilakukan monitoring yaitu;

a Merujuk pada UU No. 23 tahun 2011, pembentukan LAZ mendapatkan izin dari Menteri dan rekomendasi dari BAZNAS.

b Pada risiko ini, BAZNAS mencari sumber permasalahannya yang terjadi, apabila memiliki yang dampak besar bagi dunia zakat maka BAZNAS dapat mencabut rekomendasi yang diberikan kepada LAZ ataupun BAZNAS dapat melaporkan kepada pemerintah.

2 Risiko pada pengelolaan dana zakat

2.1 Pada risiko adanya pemanfaatan dana zakat untuk kepentingan golongan, risiko sebagian dana zakat digunakan untuk biaya operasional amil, risiko tidak adanya transparasi dalam pengelolaan dana zakat, risiko tidak adanya pelaporan dana zakat secara periodik, monitoring yang ilakukan pada risiko ini, yaitu dengan melakukan audit internal yang bertugas melakukan penilaian atas berbagai risiko, memantau kegiatan operasional BAZNAS, dan melaporkan evaluasi ke level top management mengenai temuan dari tim audit.

2.2 Tidak ada SOP (standard operational procedure) dalam pengelolaan dana zakat, pada risiko tingkat ini sulit dilakukan monitoring karena tidak mempunyai SOP, sehingga hal pertama yang harus dilakukan adalah membentuk SOP, SOP disusun dan disetujui manajemen, kemudian diterapkan dalam kegiatan operasional. Kedua, dalam menerapkan SOP dapat dilakuakn evaluasi secara triwulan ataupun kuartal sehingga dapat dilihat apakah SOP telah berjalan sesuai dengan fungsinya

2.3 Pada risiko lambatnya respon lembaga amil terhadap keluhan masyarakat dan risiko lambatnya respon lembaga amil terhadap masukan/saran dari masyarakat, pengabaian pada risiko ini kan berdampak pada reputasi amil. Sehingga monitoring yang dapat dilakukan yaitu BAZNAS menyediakan kotak saran dan kritik, membuat kuesioner tingkat kepuasan terhadap BAZNAS, atau mengunjungi masyarakat secara periodik melalui survey yang telah ditentukan sebelumnya.

2.4 Tidak sinkronnya pelaporan dana zakat antara pusat dan daerah, pada risiko ini 
monitoring dapat dilakukan dengan mewajibkan setiap BAZNAS provinsi/kabupaten memberikan laporan setiap triwulan, kuartal dan tahunan, serta BAZNAS menciptakan sistem IT yang dapat diakses oleh BAZNAS pusat sehingga dapat mempermudah BAZNAS pusat dalam monitoring.

2.5 Lemahnya manajemen database mustahik, pada risiko ini BAZNAS melakukan monitoring dengan selektif dalam menentukan mustahik dan sebaiknya bekerja sama dengan BAZ dan LAZ lainnya dalam menentukan mustahik yang benar-benar layak sebagai penerima zakat, hal ini juga dapat menghindari terjadinya penerimaan zakat 2 kali pada mustahik.

3 Risiko pada penyaluran/pendistribusian dana zakat

Pada risiko ini tidak terdapat risiko yang termasuk kedalam kategori unacceptable. Proses monitoring pada lembaga zakat mempunyai manfaat dan tujuan, sebagai berikut:

3.1 Dengan melakukan monitong dapat dipantau penyaluran zakat ke mustahik.

3.2 Monitoring dapat mencegah terjadinya kecurangan ataupun manipulasi data yang dilakukan oleh mustahik, karena mereka mengetahui adanya pemantauan dari lembaga amil sehingga mereka akan lebih hati-hati dalam berindak.

3.3 Dapat diketahui apakah zakat yang disalurkan dipergunakan dengan baik.

3.4 Dapat mengetahui apakah zakat yang disalurkan sudah sesuai kebutuhan mustahik/tepat sasaran ataukah perlu dilakukan perbedayaan program zakat.

\section{Implikasi Manajerial}

Pada tahap implikasi manajerial dapat disesuikan dengan sasaran kerangka kerja COSO yang terdiri dari 4 kategori, yaitu strategic, operating, reporting, dan compliance.

\section{Bidang Strategic}

BAZNAS menyiapkan SDM yang handal, produktif untuk mengurangi ketergantungan pada key person. Selain itu kriteria SDM yang tidak kalah pentingnya yaitu SDM yang berakhlak mulia, jujur dan dapat dipercaya. Pada kriteria ini diharapkan dapat mengurangi risiko seperti; risiko penggelapan dana zakat, risiko kecurangan dalam penyaluran dana zakat.

\section{Bidang Operating}

a Melaksanakan continuous improvement, yaitu pelaksanaan perbaikan berkesinambungan dalam memberikan usulan terhadap identifikasi potensi perbaikan dan peningkatan atau sumbangan saran untuk pencapaian visi dan misi BAZNAS sebagai lembaga amil.

b BAZNAS perlu menjaga reputasi amil, yaitu dengan menjaga kepercayaan masyarakat dengan baik, melakukan pemantauan dalam penyaluran zakat.

c BAZNAS perlu merancang sebuah proses kerja yang bertugas memantau jalannya operasional. Dengan demikian dapat dipantau kegiatan apa saja yang terjadi dalam lingkungan BAZNAS.

\section{Bidang Reporting}

BAZNAS perlu melakukan penyampaian informasi kepada masyarakat terkait dengan kegiatan dan pencapaian yang telah dilakukan oleh BAZNAS kepada masyarakat, melalui media cetak ataupun elektronik.

4 Bidang Compliance

a BAZNAS melaksanakan prosedur sesuai peraturan dan undang-undang yang berlaku serta tetap berpedoman pada syariat Islam dalam melaksanakan operasionalnya.

b Melaksanakan UU No. 23 Tahun 2011 tentang Pengelolaan Zakat, yang mengatur mengenai perencanaan, pelaksanaan dan pengkoordinasian dalam pengumpulan, pendistribusian dan pendayagunaan zakat. 


\section{SIMPULAN DAN SARAN}

\section{Simpulan}

Dengan penerapan manajemen risiko pada lembaga zakat, akan memungkinkan tercapainya tujuan organisasi, serta dapat miminimalisasi terjadinya risiko besar. Dengan penerapan manajemen risiko pada lembaga zakat diharapkan bisa menambah rasa kepercayaan umat, baik muzaki maupun mustahik terlahap lemabaga tersebut.

Dari hasil penelitian ini bahwa risiko yang ditemukan temasuk dalam kategori minor. Dalam penelitian ini, total risiko yang teridentifikasi sebanyak 60 risiko. Peristiwa risiko dibagi menjadi 3 kelompok, yaitu risiko pengumpulan dana teridentifikasi sebanyak 16 risiko, risiko pengelolaan dana zakat teridentifikasi sebanyak 26 risiko, dan risiko pendistribusian teridentifikasi sebanyak 18 risiko.

Setiap tingkat risiko yang teridentifikasi dibagi menjadi 4 kategori, yaitu kategori negligible, acceptable, undesirable, dan unacceptable. Untuk kategori risiko negligible tidak terdapat risiko yang teridentifikasi. Risiko yang teridentifasi pada kategori acceptable sebanyak 13, risiko yang teridentifikasi pada kategori undesirable sebanyak 33, dan risiko yang teridentifikasi pada klasifikasi unacceptable sebanyak 14.

Respon risiko yang disarankan adalah dengan menghindari risiko (risk avoidance) atau mentrasnfer risiko (risk transfer) untuk risiko yang masuk kedalam kategori unacceptable, risiko dengan kategori undesirable sebaiknya dikurangi (risk reduction), untuk risiko yang masuk ke dalam kategori acceptable, yaitu risiko dapat diterima, tetapi perlu dilakukan pengawasan agar risiko tidak berkembang menjadi high risk.

\section{Saran}

Dalam penelitian ini dapat disarankan beberapa hal terkait dengan beberapa risiko yang ditemukan, dalam meminimalisasi risiko, yaitu;

1 BAZNAS melakukan controlling ketat terhadap temuan risiko yang termasuk ke dalam high risk atau kategori unacceptable. Apabila risiko yang termasuk dalam kategori ini diabaikan maka akan berdampak buruk bagi reputasi BAZNAS. Melakukan controlling yang ketat tehadap setiap pertiga bulan, kuartal, dan tahunan.

2 BAZNAS memberikan pelatihan kepada para amil secara berkesinambungan, sehingga para amil menjadi SDM yang berkualitas.

3 BAZNAS menerapakan sistem IT yang dapat memenuhi kebutuhan seluruh operasional BAZNAS, seperti pembentukan sistem data base mustahik, sistem kepuasan pelayanan kepada mustahik/muzaki, diharapkan dengan adanya sistem ini maka diharapkan dapat;

a BAZNAS dapat memantau kegiatan para amilnya, apakah amil sudah bekerja sesuai SOP ataukah melanggar SOP

b Mengurangi terjadinya penyelewengan dana yang dilakukan oleh petugas amil

c Mengurangi ketergantungan pada amil(key person)

d Mencegah terjadinya penyaluran zakat dua kali

4 Membentuk tim khusus yang menangani pelanyanan atau kepuasan masyarakat, dengan adanya tim khusus ini maka diharapkan dapat;

a Menangani dengan cepat dan tanggap setiap terjadi keluhan terhadap BAZNAS

b Menjaga kestabilitasan reputasi BAZNAS di mata masyarakat

c Menjaga keharmonisan pada setiap BAZ dan LAZ

d Mengetahui dengan cepat seputar isu-isu yang terjadi dimasyarakat, serta dapat mengatasinya segera, minimal dapat membentengi BAZNAS 


\section{DAFTAR PUSTAKA}

Andriyanto, I. (2011) Strategi pengelolaan zakat dalam pengentasan kemiskinan, Jurnal Strategi Pengelolaan Zakat, 19 (1), 25-46.

Apriansyah, A. (2011) Studi analisis kinerja Badan Amil Zakat (BAZ) Kota Bogor dalam meningkatkan jumlah usaha produktif para mustahiq, Jurnal Ekonomi Islam Al-Infaq, 2(2), 81-97.

Bakar, M.H.A., Ghani, A.H.A. (2011) Towards achieving the quality life in the management of zakat distribution to the rightful recipients (the poor and needy), International Journal of Business and Social Science, 2(4), 273-245

[BAZNAS] Badan Amil Zakat Nasional. Manajemen risiko pengelolaan zakat. [internet]. [diunduh 2015 Maret 2]. Tersedia pada: http://pusat.baznas.go.id/berita-artikel/manajemen-risikopengelolaan-zakat.

Darmawi, H. (2006) Manajemen Risiko, ed 10, Jakarta, Bumi Aksara.

Darmawi, H. (2008) Manajemen Risiko, Jakarta, Bumi Aksara.

Fahmi, I. (2010) Manajemen Risiko: Teori, Kasus dan Solusi, Bandung, Alfabeta.

Godfrey, P.S. (1996) Control of Risk: A Guide to Systematic Management or Risk from Construction, London, CIRIA.

Hafidhuddin, D. (2002) Zakat Dalam Perekonomian Moderen, Jakarta, Gema Insani.

Hafidhuddin, D. \& Beik, I.S. (2010) Zakat development: The Indonesian's experience, Jurnal Ekonomi Islam Al-Infaq, 1(1), 1-5.

Hanafi, M.M. (2006) Manajemen Risiko. Yogyakarta: Sekolah Tinggi Ilmu Manajemen YKPN.

Ibrahim, P. (2008) Pembangunan ekonomi melalui tagihan zakat: Tinjauan empirikal, Shariah Journal, 16(2), 223-244.

Irawan, G. (2014) Analisis risiko pengeboran di wilayah aset 5 PT. Pertamina EP [tesis]. Bogor, SB IPB.

[ISO] International Organization for Standarization. ISO 31000 Risk Management [internet]. [diunduh 2015 Oktober 8]. Tersedia pada: http://www.iso.org/iso/home/standars/iso31000.htm

Jamil. (2003) Arsitektur strategik lembaga amil zakat nasional Dompet Dhuafa Republika [tesis], Bogor, Institut Pertanian Bogor.

Lam, J. (2003) Enterprise Risk Management: Forum Incentives to Controls. New York (US), Wiley.

Linawati \& Sanjaya. (2015) Pengaruh penerapan enterprise risk management dan variabel kontrol terhadap nilai perusahaan di sektor keuangan, Jurnal Finesta, 3(1), 52-57.

Khotimah, K. (2005) Pengaruh zakat produktif terhadap pengingkatan kesejahteraan ekonomi para mustahik, Jurnal EKSIS: Ekonomi Keuangan dan Bisnis, 1(4), 41-68.

Kountur, R. (2008) Mudah Memahami Manajemen Risiko Perusahaan. Jakarta, Penerbit PPM.

Moeller, R. (2007) COSO enterprise risk management: understanding the new integrated ERM framework, New York, Wiley.

Mufraini, M.A. (2005) Efek distribusi produktif dana zakat infak dan sedekah (ZIS) pada prilaku konsumsi mustahik, Jurnal Ekonomi Keuangan dan Bisnis Islam, 1(4), 3-39.

Roeshardianto, P. (2014) Analisis risiko dan strategi mitigasi pada proyek EPC pembangunan pembangkit listrik tenaga minihidro di PT. XYZ [tesis]. Bogor, SB IPB.

Shalihati, F. (2010) Analisis persepsi dan sikap muzaki terhadap Badan Amil Zakat Nasional di Kota Jakarta [tesis]. Bogor, Institut Pertanian Bogor.

Siregar, E.Y. (2003) Kinerja Lembaga Amil Zakat (LAZ) Nasional Dompet Dhuafa Republika dalam pengelolaan dana ZIS [tesis]. Bogor, Institut Pertanian Bogor.

Suhendra, E.S., Oswari, T., \& Setiawan, S. (2013) Peran business continuity plan dalam meminimalisir risiko teknologi informasi pada industri asuransi, Jurnal Asuransi dan Manajemen Risiko, 1(1), 42-54.

Syatir, A., Multifiah, \& Manzilati, A. (2013) Kelembagaan zakat dan preferensi muzakki. Jurnal Ekonomi Islam Al-Infaq, 4(1), 147-154. 
Wasito. (2013) Manajemen risiko pada unit yayasan studi kasus pada PT. Samboja Lodge [tesis]. Bogor, SB IPB.

Wiryono, S.K. \& Suharto. (2008) Analisis risiko operasional di PT. Telkom dengan pendekatan metode ERM, Jurnal Manajemen Teknologi, 7(1), 58-90. 